\title{
Building Stone Treasure Troves
}

\author{
Sidney Horenstein
}

Published online: 9 October 2008

(C) Springer Science + Business Media, LLC 2008
As a result of this large worldwide increase in quarry activity, a great variety of rocks from almost every division of the geologic column arrives in the marketplace.

For the teacher who wants to use this available resource for lessons, the first challenge is locating appropriate stones in a building or other structure. Excursions for lower grades may only require the teacher to name the rocks and point out obvious features such as fossils and bedding (for illustrations of fossils, see Arduini 1987 and Horenstein 1988). There are also numerous web sites about fossils. For a start, try http:// www.ucmp.berkeley.edu/exhibits/index.php and http://www. fossils-facts-and-finds.com. At higher levels, geology teachers would want to include the rocks' geologic occurrence. To eliminate confusion, stones in this paper are defined as rocks used by people - such as building stone, stone walls, stone pavements, and so on, while rocks are the materials found in their natural setting that have not been so used. Rock specimens used by students should still be called rocks.

If a teacher does not live in a community for which a guidebook or a list of stone installations has been written or compiled (see appendix), the next step is to find a stone dealer that is willing to help and who knows where the particular stones are installed (finding a local dealer or supplier on www.google.com, www.msn.com, and www. yahoo.com is easy: just list the state, or in many cases the city, and the resulting display in varying forms - mostly ads - will direct you to the business). Keep in mind that a guidebook for a distant city is not entirely useless, especially for stones that have a national or international distribution, especially if the guide contains images. Of course, some stones have only a limited local distribution, which the geology instructor would usually know about. Many guidebooks contain good examples for conducting excursions.

If you have the opportunity to look at available stone samples at a stone dealer's store, do not be disappointed if the proprietor may only know the commercial name and perhaps where it comes from-Italy, for example. If you 
feel comfortable, you may also ask for samples of stones that are no longer available for sale but have been used in local buildings in the past. The labels will usually only have the commercial names on the stone as well as the dealer name. Surprisingly, some building managers may actually know the name of the stone used in their structure and perhaps where the material comes from. While there is considerable diversity in the exterior facades of buildings, including the interior lobby will often give the teacher a wider range of stone types. Many building stones are not suitable for exterior use but are for interior use. While in the past there usually was no difficulty in bringing a class into a lobby, today's heightened security demands make it more difficult. Any field trip plans should include prior permission to visit.

Finding the information about a particular stone, especially older, no longer quarried types, may take a considerable amount of detective work, but that is the fun of it. After obtaining information about where a stone is quarried either from a stone dealer, guide, or organization such as the Marble Institute of America http://www.marble-institute.com or Building Stone Institute http://buildingstoneinstitute.org, searching the literature for geological information is made relatively easier by such index databases as Geoscience World http://geoscienceworld.org. Winkler (1997) provides an up-to-date text on the properties and durability of stone, and Hannibal and Park (1992) provides an extensive list of selected sources of information on building stones.

Particular stones may be popular for a while, then go out of production for a variety of reasons - such as changes in color tastes, weathering issues, or the quarry is no longer in, operation. The stones may no longer be wanted or quarried but to remain open the business may sometimes import blocks of stone from other quarries for sale. In that case, a stone can be said to be from a particular quarry when in fact it came from elsewhere. Building stones have great appeal because of their color, general appearance, and the geologic stories they tell, but you should be forewarned that if your main goal is to locate fossiliferous material, you will find the other groups of rocks equally compelling to your students who will want to know about them too.

Therefore, this article makes reference to all types of building stones. For the teacher uninitiated in geology, it does not take long to learn the three basic groups of rock classified on the basis of origin. Igneous rocks were once molten rock that forms deep in the earth's crust and cools and crystallizes there (example: granite) or erupts onto the surface in the form of lava (example: basalt). Sedimentary rocks form on the land or in the sea and are layered and may contain fossils (sandstone, limestone). Shale is one of several sedimentary rocks that are not suitable as a building stone. Metamorphic rocks are rocks that have been changed by heat and or pressure, a process that also takes place deep below the surface. For example, a sedimentary rock containing fossils will lose all traces of life if the degree of metamorphism is great (Horenstein 1994) See also http:// pubs.usgs.gov/gip/fossils.

Teachers with a basic knowledge of rocks may find such commercial descriptions as "black granite" somewhat confusing (Horenstein 1990). It turns out that in the building stones industry, for the most part, the term granite includes any hard rock that can be polished, which lumps almost all of the igneous (from granite to gabbro) as well as many of the metamorphic rocks (from various gneisses to quartzite) into this category. Most soft rocks that can be polished that are not "granite" are grouped together as marble and include true marble, many limestones, and serpentinites. Therefore, do not overlook stones with the commercial name "marble" or reject them as nonfossiliferous just because the name implies a metamorphic rock and where any fossils that may have existed in the original parent material were destroyed by metamorphism. The commercial designation limestone includes carbonate rocks that cannot be polished, while the metamorphic rock slate is in a category by itself.

The "Appendix" contains a selected list of guide books of particular cities as well as a list of building stone resources by state. It does not make reference to studies that are entirely devoted to granite, but an excellent web resource is http://quarriesandbeyond.org/index.html.

The scientific and semipopular literature for imported materials is enormous and much of it non-English, although many commercial listings on the web are also in English. In addition, publications directly related to the building and dimension stone industry have not been included here. Teachers who want to expand their knowledge of this multidisciplinary subject should consult, for a start, the magazine Stoneworld (http://Stoneworld.com). One excellent source for images of stones is http://stone.network.com and A Web Gallery of Stone Buildings and their Building Stones (http://gly.uga.edu/railsback/BS-Main.html), as well as the web pages of building stone suppliers, especially useful if a community is lacking in stone buildings.

Once you have the name of a fossiliferous (or any other) stone and its company or country of origin, find geologic information by starting with some research at http://www. geoscienceworld.com. Commercial names often do not give you much information. For example, "Crab Orchard Sandstone" is sandstone from Crab Orchard, TN, USA but the St. Genevieve Golden Marble is not a marble that was quarried in Ozara, St. Genevieve County, MO, USA but a Devonian age limestone containing colonial and rugose corals. Radio Black Marble on the other hand, used in Radio City Music Hall in New York, NY, USA is a black Ordovician limestone from Vermont containing large examples of the snail Maclurites sp., algae, crinoids, and early corals, but it is also called Champlain Black Marble. 


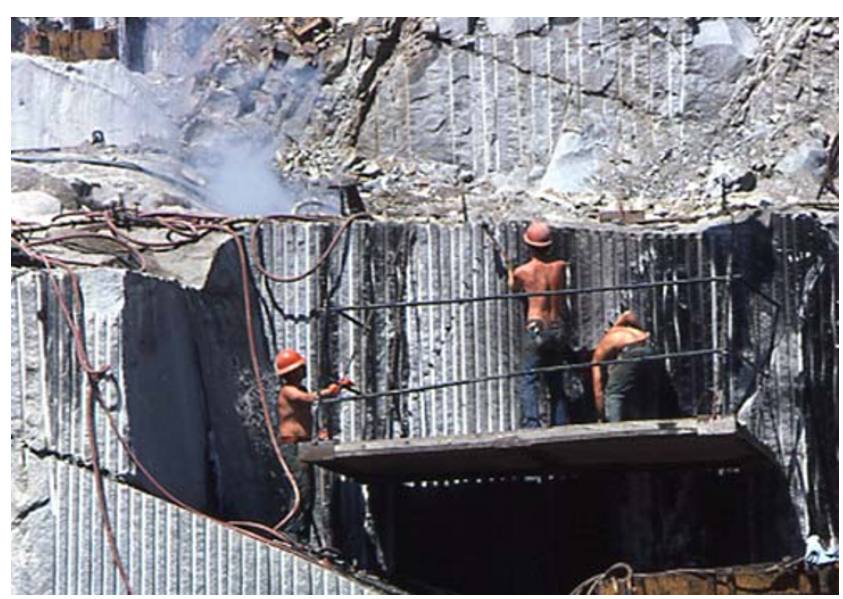

Fig. 1 Barre, Vermont granite quarry (Image by Sidney Horenstein)

Many stones have multiple names for a variety of reasons related to the commercial aspect of stone sales, including competition with other dealers. As stated earlier, you will find fossils in buildings throughout the Phanerozoic (Paleozoic, Mesozoic, Cenozoic eras), but they are generally most abundant in rocks formed during the Ordovician, Devonian, Jurassic, and Cretaceous times when the continents were covered with large epicontinental seas.

It is an unhappy surprise when a favorite building stone disappears because its building is demolished or new owners remodel the lobby or facade. Normally, the material is not recycled into another building but is destroyed and ends up in a land fill. One hopes to find out about the renovation early so that some samples can be saved for class use. Awareness of alterations is important when using a guidebook, especially when the description of a stone just does not add up. One way to avoid this problem is only to visit historic landmarks. On the other hand, it is of interest to know why the alteration took place.

Most of my experience studying building stones has been in metropolitan New York. Unlike many other localities, New York City is endowed with numerous rock outcrops, often conveniently located in New York City parks. Although easily accessible, their diversity is limited to a small variety of metamorphic rocks and even smaller sampling of sedimentary rocks. But New York City harbors a treasure trove of rocks in the building facades, lobbies, rest rooms, storefronts, sidewalks, and curb stones, among other sites. Thanks to the rich architectural history of the city and the wide use of building stones, a great variety of rock types is readily on view not only to students of all grades but also to the general public. Many people find the fossils entombed in stone the most compelling. Some of the participants on public tours continue their search later as they travel around the city and elsewhere, looking for additional fossiliferous building stones. They are delighted when a discovery is made and on occasion call me for more detailed information about their new locality. Figures 1, 2, 3, 4, and 5 are examples of fossiliferous building stones found in New York City, while Fig. 6 was taken in a Barre, Vermont granite quarry.

My interest in the use of building stones for teaching purposes began in the mid-1960s when I found samples of building stones in the rock collection of the Geology and Geography Department of Hunter College - City University of New York. At the time, I was teaching an evening course in introductory geology that included several units in mineral and rock identification. Although a field trip was conducted to nearby parks (including Central Park), it did not expose the students to the variety of rock formations that they would have seen on a formal bus trip to localities outside the city. Such field trips were not organized then because most of the students had daytime jobs. See Kemp (1992) and Wetzel (2002) for examples of student tours and projects related to buildings tours and class projects.

To rectify this deficiency somewhat, I asked students to examine a city street near their job or home to identify the rocks in facades. Their assignment came after the units on mineral and rocks identification were completed. Here was a practical application of what they learned in class to a real-world situation. Not only did identification of rocks become important but, students also became aware of which stones held up well in building facades and which ones exhibited signs of weathering. They were asked to evaluate the conditions that caused the excessive weathering.

I was confident that each student could identify at least ten varieties of rocks (at least one had to contain fossils), and not only did that turn out to be true but some of them also added notes about the building history, and a few added the commercial names of the dimension stones. Obviously, they did some additional homework. One of the educational rewards was that some of the students not only became interested in a practical aspect of geology but also in architecture, as well as the historical aspects of the

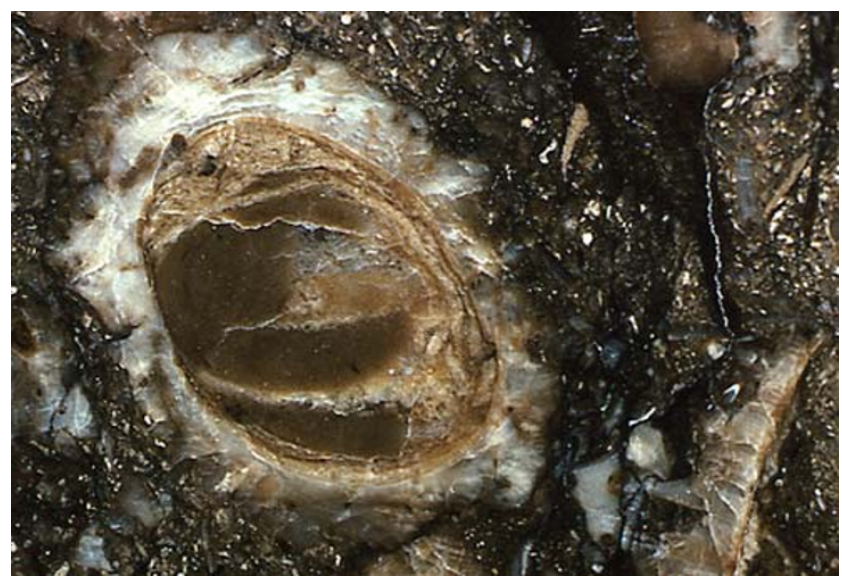

Fig. 2 Rudistid, Trieste, Italy, Cretaceous (Image by Sidney Horenstein) 


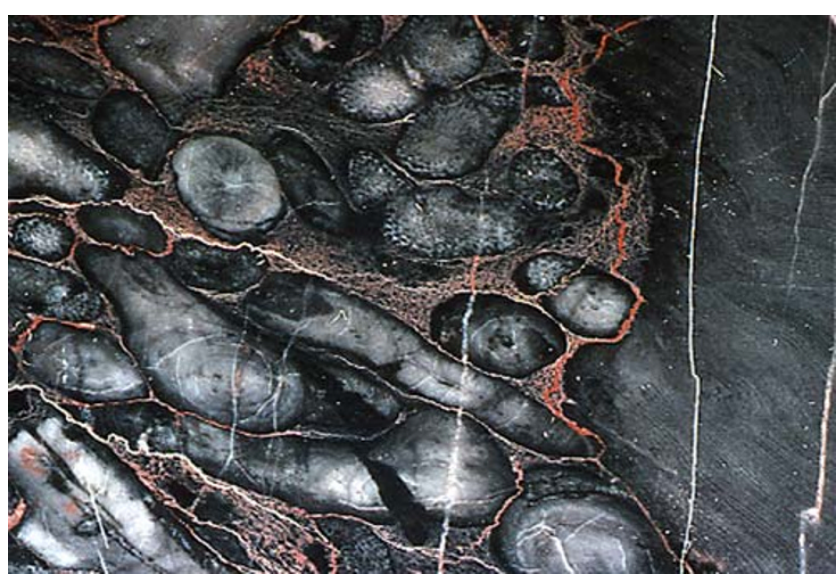

Fig. 3 Coral-stromatoporoid reef, Devon England, Devonian (Image by Sidney Horenstein)

building and its site. Thus, the study of building stones can be truly multidisciplinary, including history of mining and quarrying, tools for stone work, and for example, the labor movement in the stone industry and international financing of building projects.

For advanced geology classes, assignments can include creating an illustrated guidebook with descriptions of the buildings or structures, detailed descriptions of the mineralogy and fabric of the rock, other features such as fossils and stylolites, as well as how well the stone has performed in terms of weathering and an appropriate substitute for the poorly performing stone.

The choice of a particular stone for a project is based on many factors, including the architect's design, availability of material, appearance of the stone, where the stone is used in the project, appropriate physical properties such as compression and water absorption, suitable mineral composition for the particular climate, and very often, cost. Because they often need less stringent requirements, stones used for interior settings contain a much broader range of rock types than those used for exterior facades, monuments, and curbing. In addition, lobbies

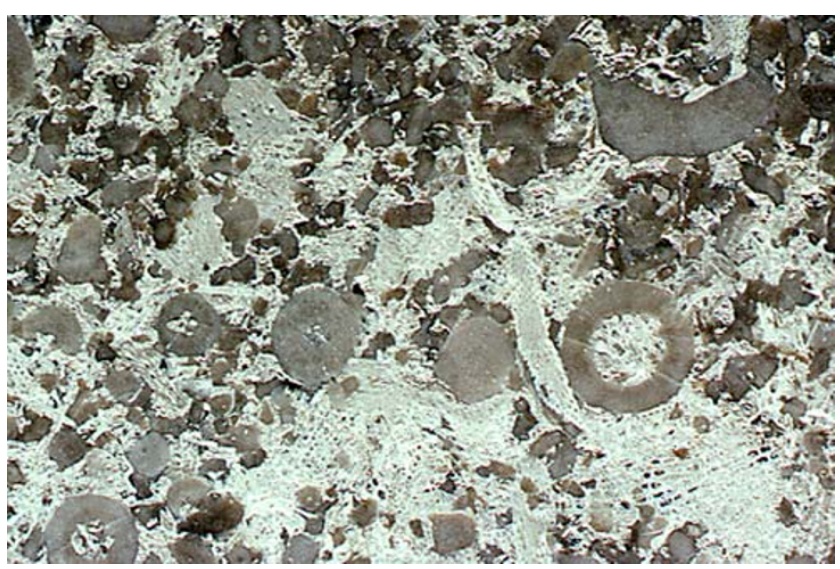

Fig. 4 Crinoids and bryozoans, Indiana Limestone, Mississippian (Image by Sidney Horenstein)

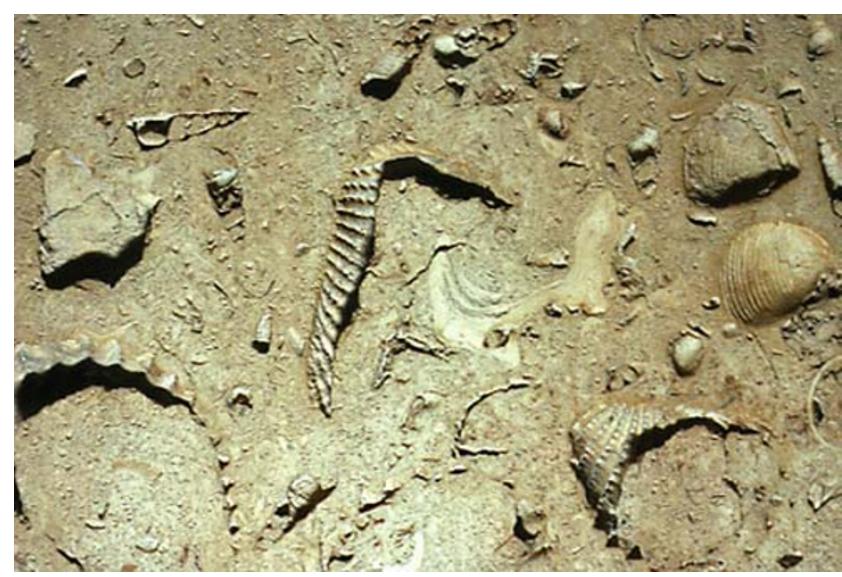

Fig. 5 Clams - Texas, Cretaceous (Image by Sidney Horenstein)

tend to be somewhat more exuberant in color than exterior facades. Choice of material takes into account amount of rainfall, climate, and occurrence of temperatures below freezing. Another important issue is the susceptibility of a stone to disruption by crystallization of salt used to melt ice during the winter. All of these factors result in the great variety of stone available for examination during building stones field trips.

After a few semesters of teaching geology in the New York City, I began to accumulate a list of "interesting" stones in the buildings around Manhattan. Later, I led field trips for an amateur fossil club, the New York Paleontological Society, stressing the paleontological aspects of the building stones and for the general public through the auspices of the American Museum of Natural History. The free public tours organized by the fossil club were an attempt to make the group known to the public and bring in new members, while the museum field trips were part of the educational outreach of the organization.

These trips caught the attention of the press and a number of articles were written about them over the years (see, for example, Steinmann 1978; Stoler 1980; Panek 1991; McFall and Wollin 1982; Mindlin 2006). Even my children were asked to write an article (Horenstein and Horenstein 1981).

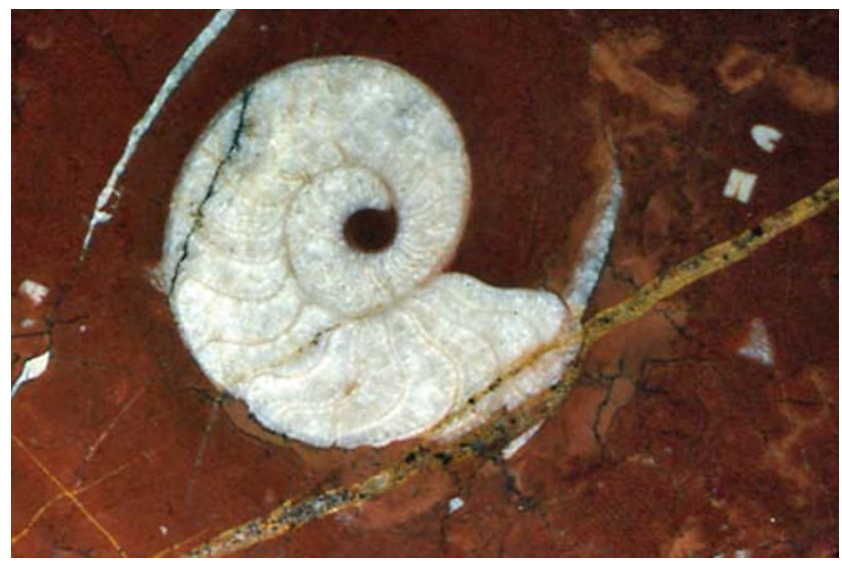

Fig. 6 Goniatite-France, Devonian (Image by Sidney Horenstein) 


\section{Appendix}

Building stone guides by locality

ARIZONA, FLAGSTAFF

Jackson, Marie D. (1999)

Stone Landmark's: Flagstaff's geology and historic building stones

Piedra Azul Press, 128 pages

BRITISH, COLUMBIA

Hora, Z.D. and L.B. Miller (1994)

Dimension Stone in Victoria, B.C.: city guide and walking tour

British Columbia Geological Survey, Information Circular 1994-15, 43 pages

\section{COLORADO, DENVER}

Murphy, Jack (1995)

Geology Tour of Denver's Buildings and Monuments

Denver Museum of Natural History, 96 pages

GEORGIA, ATLANTA

Dooley, Robert E. (1973)

Building stones of downtown Atlanta

Bulletin of the Georgia Academy of Science, vol.31, no. 2 , p. 81

INDIANA, INDIANAPOLIS

Mirsky, Arthur (1999)

Guidebook of building stones in downtown Indianapolis ( $8^{\text {th }}$ edition)

Indiana University-Purdue University at Indianapolis, 72 pages

\section{ILLINOIS, MONMOUTH}

Wiedman, L.A., R. Pletz and K.A. Emmert (1988)

A geological and historical walking tour of Monmouth, Illinois

Monmouth College Press, 32 pages

\section{KANSAS, WICHITA}

Skelton, Lawrence (1997)

Wichita's building blocks: A guide to building stones and geological features

Kansas Geological Survey

Educational Series 11, 28 pp.

\section{LOUISIANA, NEW ORLEANS}

Slagle, E.S. (1982)

A tour guide to the building stones of New Orleans

New Orleans Geological Society, 68 pp
MARYLAND, BALTIMORE

McCann-Murray, Sherry ()

A geologic walking tour of building stones of downtown

Baltimore, Maryland

www.mgs.md.gov/esic/features/walking/index.html

MASSACHUSETTS, BOSTON

Crosby, William Otis and G. F. Loughlin (1904)

A descriptive catalogue of the building stones of Boston and vicinity

Tech. Quart. 17, pp. 165-185

MASSACHUSETTS, (HARVARD UNIVERSITY)

Williams, David B. (1997)

A geologist's Harvard

www.seanet.com $\sim$ wingate/Harvard\%20Rock.pdf

MINNESOTA, ST. PAUL

Kain, Joan (1978)

Rocky roots - three walking tours of downtown St. Paul

Ramsey County Historical Society, 32 pages

MISSOURI, ST. LOUIS

Hebrank, A.W. (1989)

The geologic story of the St. Louis riverfront (a walking tour) Missouri Department of Natural Resources, Division of Geology and Land Survey, Special Publication 6, 48 pages

NEW YORK, ALBANY

Fickies, R. H. and R.J. Dineen, R. J. (1979)

The building stones of the Nelson A. Rockefeller Empire State Plaza

IN: Friedman, G. M. Editor

Joint annual meeting of New York State Geological Association, 51st annual meeting and New England intercollegiate geological conference,

71st annual meeting; guidebook

Annual Meeting of the New York State Geological Association, no. 51, pp.318-325

NEW YORK, ALBANY

Fickies, R. H. (1986)

Building stones of the Empire State Plaza; a walking tour New York State Museum Educational Leaflet 27, 12 pages

\section{NEW YORK (CORNELL UNIVERSITY)}

Chiment, J.J. (1999)

Building stones on the Cornell campus

http://www.cornell.edu/search/index.cfm?tab $=$ facts $\&$ $\mathrm{q}=\& \mathrm{id}=1101$

\section{NEW YORK, NEW YORK}

Steinmann, Marion (1978)

Fossil Hunters find ancient treasures around Manhattan Smithsonian, vol. 9, pp. 143-151 
NEW YORK, NEW YORK

Stoler, Peter (1980)

Stalking the city fossil

Discover, vol. 10 , no. 10 , pp. 55, 56

NEW YORK, NEW YORK

Horenstein, Sidney and John Patton (1986)

Appendix II Varieties of stone in the New York Public Library

IN: Reed, Henry Hope

The New York Public Library, W.W. Norton, pp. 276, 277

\section{NEW YORK, NEW YORK}

Horenstein, Sidney (1989)

Building stones of the New York City area

IN: Baskerville, Charles (Editor) Environmental, engineering, and urban geology of the New York Metropolitan area, Volume 1, American Geophysical Union, pp. 2-14

\section{NEW YORK, SCHENECTADY}

Hollocher, Janet and Kurt Hollocher (1995)

Building stones of Schenectady, New York

Field trip guidebook for the 67th annual meeting of the New York State Geological Association

IN: Garver, John I and Jacqueline A. Smith (Editors)

Guidebook-New York State Geological Association, Meeting, vol. 67, pp. 275-291

\section{NEW YORK, SYRACUSE}

Nye, O. B., Jr and R. Fazio. (1978)

Building stones used in the vicinity of Syracuse

IN: Merriam, D. F. (Editor)

New York State Geological Association guidebook, 50th annual meeting, pp. 354-367

\section{NORTH CAROLINA, RALEIGH}

Carpenter, P. Albert (2001)

Building stone used in historical and modern architecture of downtown Raleigh, North Carolina; a walking tour Guidebook - Geological Society of America, Southeastern Section, pp. 119-134

\section{NOVA SCOTIA, HALIFAX}

Brown, Yvonne, Martha Devanney, Howard Donohoe, Susan Doyle and Margaret Shaw (1989)

A walking tour of rocks, minerals, and building stones in downtown Halifax

Nova Scotia Department of Mines and Energy, Information Circular 3, [8 pages]

\section{NOVA SCOTIA, HALIFAX}

Bishop, Katherine, Martha Devanney, Anne Stevenson and Howard Donohoe (1989)
A walking tour of rocks, minerals and building stones of Spring Garden Road, Halifax

Nova Scotia Department of Mines and Energy, Information Circular 10, [10 pages]

\section{OHIO, AKRON}

Hannibal, Joseph T. (2006)

Guide to the building stones and cultural geology of Akron Ohio Geological Survey, Report 19, 75 pages

\section{OHIO, CINCINNATI}

Hannibal, Joseph T. and Richard Arnold Davis (1992), Guide to the building stones of downtown Cincinnati; a walking tour

Ohio Geological Survey, Guidebook 7, 44 pages

\section{OHIO, CLEVELAND}

Hannibal, Joseph T. and Mark T. Schmidt (1992)

Guide to the building stones of downtown Cleveland; a walking tour

Ohio Geological Survey, Guidebook 5, 33 pages

OHIO, COLUMBUS

Mayer, Mona (1962)

Fossils in the Ohio State House

Explorer, vol. 4, pp. 20-23

OHIO, COLUMBUS

Melvin, Ruth W and Garry D. McKenzie (1997)

Guide to the building stones of downtown Columbus; a walking tour

Ohio Geological Survey, Guidebook 6, 33 pages

OHIO, TOLEDO

Camp, Mark J. (1994)

Early uses of ceramics and building stone in downtown Toledo

The Ohio Journal of Science, vol. 94, no. 2, pp. 28, 29.

OHIO, TOLEDO

Meinhart, James M. (2006)

Building Stones of Toledo Ohio: a survey of dimension stone use in significant structures

Thesis (M.S.) University of Toledo, 358 pages

ONTARIO, OTTAWA

Lawrence, D.E. (2001)

Building stones of Canada's Federal Parliament buildings Geoscience Canada, vol 28, no. 1, pp 13-30

ONTARIO, OTTAWA

Freeman, E.B. (2003) 
Geology of Parliament buildings; 3, Building stones of Ontario's Provincial Parliament building

Geoscience Canada, vol 30, no. 2, pp 43-57

\section{PENNSYLVANIA, HARRISBURG}

Geyer, A. R. (1977)

Building stones of Pennsylvania's capital area

Pennsylvania Geological Survey, Fourth Series,

Environmental Geology Report, no. 5, 47 pages

TENNESSEE, CHATTANOOGA

Wilson, R.L. (1979)

Building stone of downtown Chattanooga

Privately published by author, $63 \mathrm{pp}$.

TEXAS, AUSTIN

Ellison, S.P. and Joseph J. Jones

Walking the Forty Acres: Building Stones-Precambrian to Pleistocene

www.lib.utexas.edu/geol/fortyacres/40acres3.html

\section{TEXAS, HOUSTON}

Galey, John, D.A. Des Autels and K.A. McDonald (1988) Building stones of Houston; Houston city hall; One Shell Plaza, Houston public library, the downtown Exxon building, Republicbank center, and 1600 Smith

Bulletin Houston Geological Society, vol. 30, no. 10, pp 20-33

\section{TEXAS, HOUSTON}

McDonald, Kathleen A., A. L. Austin, David L. Risch and Dean Ayres (1989)

Building stones of Houston; Texas Commerce Tower, First City Tower, Interfirst Plaza, Lyric Office Center Bulletin Houston Geological Society, vol 32, no. 3, pp 24-27

\section{TEXAS, HOUSTON}

Galey, John and K.A. McDonald (1988)

Building stones of Houston

Bulletin Houston Geological Society, vol 31, no. 4, pp 15-19

\section{UTAH, SALT LAKE CITY}

Utah Geological Survey

Building stones of downtown Salt Lake City

http://geology.utah.gov/online_html/pi/pi-60/index.htm

WASHINGTON, D.C.

Smithsonian Institution (1848)

Reports on building stones for the Smithsonian Institution Annual Report Smithsonian Institution, vol 2, pp 4-74, 105-107, 109-114, 119, 121-122
WASHINGTON, D.C.

Withington, Charles F. (1975)

Buildings stones of our Nation's Capitol

U.S. Government Printing Office, 44 pages

WASHINGTON, D.C.

O’Connor, James V. (1989)

Building stones of Pennsylvania Avenue

IN: Moore, John E, Julia A. Jackson and Joan M. Rubin (Editors)

Geology, hydrology and history of the Washington, D.C. area

American Geophysical Institute, pp 9-16

WASHINGTON, D.C.

McGee, Elaine S. (1990)

Deterioration of building stones in Washington, DC; a field trip guide

U. S. Geological Survey, Open-File Report: OF 90-0479, 16 pages

WASHINGTON, D.C.

Olson, Don and Charles F. Withington (1998)

Buildings stones of our Nation's Capitol

United States Geological Survey, 36 pages

\section{WASHINGTON, SPOKANE}

McKelvey, G. E., Bonnie B. Bunning, F. William Burnet, Mike Hamilton and Byron Swanson (1981)

Cornerstones of Spokane; a guidebook to the building stones of downtown Spokane

Northwest Min. Assoc., 47 pages

\section{WEST VIRGINIA, MORGANTOWN}

Corbett, R.G. and A.E. Burford (1968)

Building stone in downtown Morgantown, West Virginia

Proceedings of the West Virginia Academy of Science 1967, vol 39, pp 327-336

Building stone resources by state

(The list does not include publications for granite only. Many of the publications indicate where the product was installed. This list is not complete; consult Bibliography of Geology. U.S. Geological Survey or for example GeoRef on line.)

\section{ALASKA}

Wright, Charles W. (1908)

The building stones and materials of southeastern Alaska

U.S. Geological Survey Bulletin 345-B, pp 116-126

\section{ALASKA}

Burchard, E.F. (1920)

Marble resources of southeastern Alaska

U.S. Geological Survey Bulletin 682, 118 pages 
ARIZONA

Culin, Frank L., Jr. (1916)

Building stones

Arizona Bureau of Mines Bulletin, 11 pages.

CALIFORNIA

Jackson, Abraham Wendell (1888)

Building stones

Annual Report of the State Mineralogist for 1888, pp 885-894

\section{CALIFORNIA}

Aubury, L.E. (1906)

The structural and industrial materials of California, Part 1, Building Stones

California State Mining Bureau Bulletin No. 38, pp 13-170

\section{CANADA}

Parks, W.A. (1912-1917)

Report on the building and ornamental stones of Canada Canada Department of Mines Branch, five volumes

\section{COLORADO}

Lakes, Arthur (1901)

Sedimentary building stones of Colorado

Mines Minerals, vol 22, pp 62-64

\section{CONNECTICUT}

Moore, F.H. (1935)

Marbles and limestones of Connecticut

Connecticut Geological Natural History Survey Bulletin 56,56 pages

\section{ILLINOIS}

Lamar, John Everts and Harold Bowen Willman (1955)

Illinois building stones

Illinois State Geological Survey Report of Investigations., no. 184,24 pages

\section{INDIANA}

Logan, William Newton (1921)

The building stones of Indiana

Indiana, Dept. Conservation, 2nd Annual Report, pp 257-263

\section{INDIANA}

Keith, Brian, and Todd A. Thompson (2002)

Salem Limestone in dimension stone quarries in Indiana Indiana Geological Survey, Guidebook 15, 26 pages

\section{IOWA}

Houser, Gilbert (1893)

Some lime-burning dolomites and dolomitic building stones from the Niagara of Iowa

Annual Report of the State Geologist for 1893, pp 197-207
IOWA

Day, William C. (1895)

Notes of Iowa building stone

IN: Sixteenth Annual Report of the United States Geological Survey Part IV. Mineral Resources of the United States, 1894, Nonmetallic Products, pp 500-502

IOWA

Beyer, S.W. and I.A. Williams (1907)

The geology of quarry products

Iowa Geological Survey Annual Report, vol 17, pp 185-525

IOWA

Witzke, Brian (2001)

Geologic Sources of Historic Stone Architecture in Iowa http://www.igsb.uiowa.edu/Browse/buildings/buildings.htm

\section{KANSAS}

Risser, H.E. (1960)

Kansas building stone

Kansas State Geological Survey Bulletin 142, part 2, pp 52-122

\section{KANSAS}

Grisafe, D.A. (1976)

Kansas building limestone

Kansas Geological Survey, Mineral Resources Series 4, 42 pages

\section{KENTUCKY}

Richardson, Charles Henry (1923)

The building stones of Kentucky

Kentucky Geological Survey series 6, vol 11, 355 pages

\section{MARYLAND}

Merrill, G.P. and Edward Bennett Mathews (1898)

An account of the character and distribution of Maryland building stones

Maryland Geological Survey, vol 2, part 2, pp 47-241

\section{MARYLAND}

Kuff, Karen R and James Brooks (1985)

Building stones of Maryland

www.mgs.md.gov/esic/brochures/buildst.html

\section{MICHIGAN}

Johnson, A.M. (1983)

Geologic and economic evaluation of building and decorative stone resources in Michigan

IN: Ault, C.H. and G.S. Woodward, editors, Proceedings of the 18th Forum on Geology of Industrial Minerals, Indiana Geological Survey, Occasional Paper 37, pp 113-126 


\section{MINNESOTA}

Winchell, Newton Horace (1884)

Historical sketch of explorations and surveys in Minnesota; the general physical features of Minnesota; The building stones of Minnesota

Minn. Geol. Survey, pp 1-203

\section{MINNESOTA}

Brown, C.L. (1936)

Building and ornamental stones of Minnesota

Compass, vol 17, no. 1, pp 12-15

\section{MISSOURI}

Ladd, George Edgar (1890)

Building stones, clays, and sands of Iron, Saint Francois, and Madison Counties, Missouri

Missouri Bureau of Geology and Mines, 2nd Series, Bull. 1, pp 22-44

\section{MISSOURI}

Ladd, George Edgar (1891)

Notes on the clays and building stones of certain western central counties tributary to Kansas City

Missouri Bureau of Geology and Mines, 2nd Series, Bull. 5, pp 43-86

\section{MISSOURI}

Buckley, E.R. and H.A. Buehler (1904)

The quarrying industry of Missouri

Missouri Bureau of Geology and Mines, Vol 2, Series 2, 371 pages

\section{MONTANA}

Mansfield, G.R. (1933)

Some deposits of ornamental stone in Montana

U.S. Geological Survey Circular 4, 22 pages

\section{MONTANA}

Berg, R.B. (1974)

Building Stone in Montana

Montana Bureau of Mines and Geology Bulletin 94, 41 pages

\section{NEW BRUNSWICK}

Martin, G.L. (1990a)

For the love of stone, vol 1-The story of New Brunswick building stone industry

Department of Natural Resources and Energy Miscellaneous Report 8, 176 pages
NEW BRUNSWICK

Martin, G.L. (1990b)

For the love of stone, vol 2-The story of New Brunswick building stone industry

Department of Natural Resources and Energy Miscellaneous Report 98, 249 pages

\section{NEVADA}

Reid, John A. (1904)

Preliminary report on the building stones of Nevada Nevada University, Department of Geology, 58 pages

\section{NEW JERSEY}

Lewis, Joseph Volney (1909)

Building stones of New Jersey

Annual Report of the State Geologist of New Jersey for 1909, pp 53-124

\section{NEW YORK}

Julien, Alexis Anastay (1884)

The durability of building stones in New York City and vicinity pp. 364-393

\section{NEW YORK}

Hall, James (1886)

Report on building stones

New York State Museum Annual Report for 1886, pp 186-225

\section{NEW YORK}

Smock, J.C. (1990)

Building stone in New York

New York State Museum Bulletin 10, pp 193-369

\section{NORTH CAROLINA}

Watson, G.P. (1906)

The building and ornamental stones of North Carolina

North Carolina Geological Survey Bulletin 2, 283 pages

NORTH CAROLINA

Moneymaker, Berlen Clifford (1944)

Building stones of western North Carolina

Journal of the Tennessee Academy of Science, vol 19, no. 4, pp 280-294

\section{NORTH CAROLINA}

Carpenter, P.A. III (1983)

Building stones of North Carolina

North Carolina Geological Survey, Miscellaneous Publications, 16 pages

NOVA SCOTIA

Gilpin, Edwin (1902)

The building stones of Nova Scotia

Stone Magazine, pp 122-128 


\section{NOVA SCOTIA}

Dickie, G.B. (1988)

Building stone in Nova Scotia

Nova Scotia Department of Mines and Energy Information Circular 12, [20 pages]

OHIO

Orton, Edward (1884)

Building stones of Ohio

Bulletin, Ohio Division of Geological Survey, pp 577-642

OHIO

Bownocker, John Adams (1915)

Building stones of Ohio

Ohio Geological Survey, Bulletin 18, 160 pages

\section{OKLAHOMA}

Mayberry, J.W. (1906)

Oklahoma building stones

Thesis (M.A.) University of Kansas

\section{OKLAHOMA}

Oakes, M.C. (1923)

Building materials of Oklahoma

Oklahoma Academy of Science Proceedings, vol 3, pp 113-117

\section{ONTARIO}

Bell, Andrew (1896)

Notes on the building stones of eastern Ontario

Stone Magazine, pp. 565-567

\section{ONTARIO}

Hewitt, D.F. (1964)

Building stones of Ontario

Ontario Department of Mines, Industrial Mineral

Reports, 13-17, 305 pages

\section{PENNSYLVANIA}

Stone, Ralph Walter (1932)

Building Stones of Pennsylvania

Pennsylvania Geologic Survey, Bulletin M15, 316 pages

\section{PENNSYLVANIA}

Anonymous (1986)

Building stones from Cumberland County

Pennsylvania Geology, vol 17, no. 1, pp 10-12

\section{TENNESSEE}

Gordon, C.H., T.N. Dale and O. Bowles (1924)

Marble deposits of east Tennessee

Tennessee Division of Geology Bulletin 28, 264 pages

\section{TEXAS}

Barnes, Virgil Everett, Raymond Fillmore Dawson and George A. Parkinson (1942)

Building stones of central Texas

University of Texas, Bureau of Economic Geology, Report 4246, 198 pages

\section{TEXAS}

Aber, S.W. and D.A. Grisafe (1982)

Petrographic characteristics of Kansas building limestones

Kansas Geological Survey Bulletin 224, 37 pages

\section{TEXAS}

Garner, L.E. (1992)

The dimension stone industry of Texas

Texas Bureau of Economic Geology, Mineral Resources Circular 82, 16 pages

\section{UNITED STATES}

US 10th Census (1884)

Report on the building stones of the United States and statistics of the quarry industry for 1880

US 10th Census, vol 10, 440 pages

\section{UNITED STATES}

Merrill, G.P. (1889)

The collection of building and ornamental stones in the US National Museum - a hand-book and catalog

Annual Report of the Board of Regents of the Smithsonian Institute for 1886, part II, pp 277-648

\section{UNITED STATES}

Day, Willian Cathcart (1890)

The building stones of the United States

Journal of the Franklin Institute, pp 98-114

\section{VERMONT}

Dale, T.N. (1912)

The commercial marble of western Vermont

U.S. Geological Survey Bulletin 521, 170 pages 


\section{VIRGINIA}

O’Connor, James V. (1989)

Building stones from Northern Virginia

Virginia Journal of Science, vol 41, no. 2, p 93

\section{WASHINGTON}

Shedd, Solon (1903)

The building and ornamental stones of Washington

Washington Geological Survey, Annual Report for 1902, vol 2, part 1, pp 1-163

\section{WASHINGTON}

Moen, W.S. (1967)

Building stone of Washington

Washington Division of Mines and Geology Bulletin 55, 85 pages

\section{WISCONSIN}

On the building and ornamental stones of Wisconsin Wisconsin Geological and Natural History Survey Bulletin 4, 544 pages

\section{WYOMING}

Knight, Wilbur Clinton (1898)

The building stones and clays of Wyoming

Engineering and Mining Journal, pp 546, 547

\section{References}

Arduini P, Terruzzi G, Horenstein S. (editor) Simon and Shuster's guide to fossils. New York: Simon and Shuster; 1987. 320 pages.

Hannibal JT, Park LE. A guide to selected sources of information on stone used in buildings, monuments, and works of art. J Geol Educ. 1992;20:12-24.

Horenstein S. Familiar Fossils North America Knopf Publishers; 1988. 191 pages (CK).

Horenstein S. Rocks around the block - a variety of stone types are used for buildings and monuments. Sci World February 2, 1990, pp. TK.

Horenstein S. Rocks tell stories. Lerner Publishing Group; 1994. 72 pages.

Horenstein M, Horenstein J. What a place for fossils. Ranger Rick's Nat Mag. 1981;42-6, January.

Kemp KM. Walking tours of building stones for introductory geology classes. J Geol Educ. 1992;40:188-93.

McFall RP, Wollin J. Fossils for amateurs New York. Van Nostrand Reinhold Company; 1982. p. 286-7.

Mindlin A. Written in Stone New York Times, The City Section for 2006; June 4.

Panek R. A world's geology on a city's face. New York Times. 1991; October 4

Steinmann M. Fossil hunters find ancient treasures around Manhattan Smithsonian. 1978;9:143-51.

Stoler P. Stalking the city fossil. Discover 1980;10(10):55-6.

Wetzel LR. Building stones as resources for student research. J Geosci Educ. 2002;50(4):404-9.

Winkler, EM. Stone in Architecture: Properties, Durability New York, Springer-Verlag; 1997. 313 pages. Figures (all images by Sidney Horenstein). 